\title{
Literature Review of the Published Human Clinical Trials: On COVID-19 Vaccines
}

\section{Sarah El-Nakeep}

Internal Medicine Department, Faculty of Medicine, Ainshams University, Cairo, Egypt

\section{ABSTRACT}

Background: With the release of two vaccines after FDA approval, we are entering phase IV or as it is called Post-marketing phase. This phase is responsible for the mass vaccination and the herd immunity we need to end the pandemic.

Methods: the author searched PubMed for the keywords "Vaccine, COVID-19, and SARS-CoV2", along with following the announcements of the various scientific communities.

Results: No phase IV trial data has been published till the time being, but only published data of Phases I-II and III were found by the literature search. The author discussed the limitations of the studies and the promised outcomes measured in those studies.

Conclusions: Waiting for phase IV data yet to be published; the author has examined the benefits and limitations of each vaccine.

Keywords: Vaccine; COVID-19; SARS-CoV2; Clinical trials

\section{INTRODUCTION}

Starting from December 2019; millions of deaths, along with morbidity from COVID-19 have occurred. Those who were lucky enough to survive are another issue; people struggling with the virus effect on immunity, coagulation system, neurological system etc.

Emergency situations as COVID-19 pandemic require emergency authorizations; these are intended to shorten the time for each of the phases of the clinical trials or as termed by Pfizer 'Project Lightspeed' [1]. The aim is to have an effective vaccine that could offer protection to the population and end the pandemic in the most urgent and efficient way possible, as time elapsed equals the loss of more lives.

One ethical issue is; that infection cannot be induced in humans thus we could only depend on the individual's behavior; how strictly each participant adheres to the social distancing and the health hygiene guidelines. Another ethical dilemma; is the prohibition of inclusion of children and pregnant women due to concerns about safety (although we know that these groups are in a tremendous need for protection and are considered a high risk population for acquiring infection), thus data will

\section{Vol No: 05, Issue: 01}

Received Date: January 20, 2021

Published Date: February 16, 2021

\section{Corresponding Author}

\section{Sarah El-Nakeep}

MD, Internal Medicine Department, Faculty of Medicine, Ainshams University, Cairo, Egypt

E-mail: sarahnakeep@yahoo.com

Citation: Sarah El-Nakeep. (2021). Literature Review of the Published Human Clinical Trials: On COVID-19 Vaccines. Mathews J Immunol Allergy. (5)1:11.

Copyright: Sarah El-Nakeep. (C) 2021. This is an open-access article distributed under the terms of the Creative Commons Attribution License, which permits unrestricted use, distribution, and reproduction in any medium, provided the original author and source are credited. 
be lacking for those categories until all safety issues are to be resolved. In addition; current data on the elderly showing higher mortality and side effects could be another setback [2].

The composition of most of the vaccines includes a part of spike protein or the whole-length protein sequence. The Russian vaccine contains the whole-length of the spike protein [3] and Cansino vaccine using the Wuhan genome (Gen bank accession number YP_009724390) [4,5], while the wild-type sequence used by Novavax (accession number MN908947) forming a recombinant nanoparticle vaccine [6]. In addition to the perfusion-stabilized sequence by Moderna [7] and trimerized receptor-binding domain as in the Pfizer vaccine BNT162b1 [8] both contained in a lipid nanoparticle.

In addition; it could be carried on a vector as in the AstraOxford [9] and Russian vaccine [3) or the vector Ad26 adenovirus carrying the whole length of the spike protein as in Johnson and Johnson, with the spike protein sequence derived mostly from the original Wuhan strain (NC_045512). The recombinant Ad26 vector is the vector carrier for the approved Ebola vaccine (by the European Medicines Agency) and also under research for Zika and respiratory syncytial viruses, that explains why it has been utilized by many candidate vaccines [10]. Another vector is the inactivated Ad5 vector carrier vaccines used by Sinovac and Cansino $[4,5]$.

On another note; the new mRNA vaccines are first to be used to vaccinate humans, thus our clinical experience is still limited.

\section{Vaccines that are about to publish phase IV:}

The release of the COVID-19 vaccines to the general public started in December 2020, with one month into mass vaccination two vaccines succeeded in acquiring the approval of the FDA and one achieved the European authorization. The Russian recombinant vector vaccine ended its phase III trial last November and published their interim analysis on 2nd February 2021 [11].

But at the time being none of the trials completed their phase IV let alone published their full results. We only have data on phase I-II and some of the phase III trials (mostly interim data) as shown in table 1.

\begin{tabular}{|c|c|c|c|c|c|c|}
\hline Study /Trial registry & $\begin{array}{c}\text { Number of } \\
\text { participants/age }\end{array}$ & $\begin{array}{l}\text { Phase /type } \\
\text { of study }\end{array}$ & $\begin{array}{l}\text { Name of the } \\
\text { vaccine }\end{array}$ & Country & Approval & $\begin{array}{c}\text { Protection rate/ } \\
\text { outcome effect }\end{array}$ \\
\hline $\begin{array}{l}\text { (18) Anderson } \\
\text { (subgroup) } \\
\text { (22) Jackson- } \\
\text { NCT04283461 }\end{array}$ & $\begin{array}{l}40 \text { elderly } \\
45(18-55)\end{array}$ & $\begin{array}{l}\text { I (open } \\
\text { label-dose } \\
\text { escalation) }\end{array}$ & \multirow[b]{2}{*}{ mRNA-1273 } & \multirow[b]{2}{*}{$\begin{array}{c}\text { USA } \\
\text { (Moderna) }\end{array}$} & \multirow[b]{2}{*}{$\begin{array}{l}\text { Yes } \\
\text { FDA }\end{array}$} & Antibody titre \\
\hline $\begin{array}{c}\text { (7)Baden- } \\
\text { NCT04470427 }\end{array}$ & 30,420 & III (RCT 1:1) & & & & $\begin{array}{l}94.1 \% 185 \text { in } \\
\text { placebo/11 in } \\
\text { intervention (14 } \\
\text { days after } 1^{\text {st }} \\
\text { dose) }\end{array}$ \\
\hline $\begin{array}{l}\text { (19)Folegatti } \\
\text { NCT04324606 }\end{array}$ & $\begin{array}{c}1077 \text { participants } \\
\text { (18-55y) } \\
543 \text { ChAdOx1 } \\
534 \text { in MenACWY } \\
\left(1^{\text {st }} 10 \text { where in non- }\right. \\
\text { RCT })\end{array}$ & \multirow{2}{*}{$\begin{array}{l}\text { Phase I-II } \\
\text { (RCT) }\end{array}$} & \multirow{3}{*}{$\begin{array}{l}\text { ChAdOx1 } \\
\text { nCoV-19 }\end{array}$} & \multirow{3}{*}{$\begin{array}{l}\text { England } \\
\text { (ASTRA- } \\
\text { OXFORD) }\end{array}$} & \multirow{3}{*}{$\begin{array}{c}\text { No } \\
\text { (Only } \\
\text { European } \\
\text { approval) }\end{array}$} & \multirow{2}{*}{$\begin{array}{l}\text { Peak of T-cell } \\
\text { response } \\
\text { and antibody } \\
\text { response after } \\
14-28 \text { days }\end{array}$} \\
\hline $\begin{array}{l}\text { (20)Ramasamy } \\
\text { NCT04400838 }\end{array}$ & $\begin{array}{c}560 \text { participants } \\
100 \text { in } 18-55 \\
160 \text { aged } 56-69 \\
\text { years } \\
240 \text { aged } 70 \text { years } \\
\text { and older }\end{array}$ & & & & & \\
\hline $\begin{array}{c}\text { (9)Voysey } \\
\text { ISRCTN89951424 } \\
\text { NCT04324606 } \\
\text { NCT04400838 } \\
\text { NCT04444674 }\end{array}$ & 23,848 participants & $\begin{array}{c}\quad \text { I } \\
\text { I-II } \\
\text { I-II } \\
\text { III (RCT) }\end{array}$ & & & & $62 \cdot 1 \%$ \\
\hline
\end{tabular}




\begin{tabular}{|c|c|c|c|c|c|c|}
\hline $\begin{array}{c}\text { (6)Keech } \\
\text { NCT04368988 }\end{array}$ & $\begin{array}{c}18-59 y \text { old } \\
83 \text { with adjuvant } \\
25 \text { without adjuvant } \\
23 \text { placebo } \\
1^{\text {st }} 6 \text { pts open label } \\
1: 1 \\
\text { then } 125 \text { in } 1: 1: 1: 1: 1\end{array}$ & $\begin{array}{l}\text { I-II (RCT) } \\
\text { dose } \\
\text { escalation }\end{array}$ & $\begin{array}{c}\text { Recombinant } \\
\text { Spike Protein } \\
\text { Nanoparticle } \\
\text { NVX-CoV2373 }\end{array}$ & $\begin{array}{c}\text { Australia } \\
\text { By Novavax } \\
\text { and } \\
\text { manufactured } \\
\\
\text { at Emergent } \\
\text { Biosolutions }\end{array}$ & No & $\begin{array}{l}\text { Enhanced T-cell } \\
\text { and antibody } \\
\text { repsonse }\end{array}$ \\
\hline $\begin{array}{c}\text { (3)Logunov } \\
\text { NCT04436471 } \\
\text { NCT04437875 }\end{array}$ & $\begin{array}{c}76 \text { patients in two } \\
\text { studies }(38+38) \\
18-60 y\end{array}$ & $\begin{array}{l}\text { I-II (open } \\
\text { label) dose } \\
\text { escalation - } \\
\text { no control }\end{array}$ & \multirow{2}{*}{$\begin{array}{c}\text { rAd26 } \\
\text { and rAd5 } \\
\text { vector-based } \\
\text { heterologous } \\
\text { prime-boost } \\
\text { COVID-19 } \\
\text { (Gam-COVID- } \\
\text { Vac) }\end{array}$} & \multirow[b]{2}{*}{ Russia } & \multirow[b]{2}{*}{ No } & $\begin{array}{c}100 \% \\
\text { seroconversion }\end{array}$ \\
\hline $\begin{array}{l}\text { (11) Logunov } 2 \\
\text { NCT04530396 }\end{array}$ & $\begin{array}{l}\text { Total of } 21,977 \\
\text { participants } \\
\text { Vaccine group: } 16, \\
501 \text { participants } \\
\text { Placebo group: } \\
\text { 5,476 participants }\end{array}$ & $\begin{array}{l}\text { III RCT } \\
\text { (double } \\
\text { blind) }\end{array}$ & & & & $91 \cdot 6 \%$ efficacy \\
\hline $\begin{array}{l}\text { (15)Palacios- } \\
\text { NCT0445659 } \\
\text { (23) }\end{array}$ & $>18-59$ and $\geq 60$ & III RCT & $\begin{array}{l}\text { (Inactivated) } \\
\text { Vaccine }\end{array}$ & $\begin{array}{l}\text { China } \\
\text { by SinoVac } \\
\text { (Wuhan } \\
\text { Institute of } \\
\text { Biological } \\
\text { Products) }\end{array}$ & No & $50.4 \%$ \\
\hline (8)Mulligan & 45 (18-55y) & I-II RCT & & & & elicited robust \\
\hline (1)Sahin & $\begin{array}{l}60 \text { participants } \\
20-56 \text { years }\end{array}$ & $\begin{array}{l}\text { I-II non- } \\
\text { randomized } \\
\text { open } \\
\text { label dose } \\
\text { escalation }\end{array}$ & $\begin{array}{l}\text { RNA vaccine } \\
\text { BNT162b1 }\end{array}$ & $\begin{array}{c}\text { USA } \\
\text { (Pfizer) }\end{array}$ & No & $\begin{array}{l}\text { T cell responses } \\
\text { and strong } \\
\text { antibody } \\
\text { responses }\end{array}$ \\
\hline $\begin{array}{c}\text { (16)Polack } \\
\text { NCT04368728 }\end{array}$ & $\begin{array}{l}21,720 \text { with } \\
\text { BNT162b2 } 21,728 \\
\text { with placebo }\end{array}$ & II-III (RCT) & $\begin{array}{l}\text { BNT162b2 } \\
\text { mRNA }\end{array}$ & \multirow{2}{*}{ USA (Pfizer) } & $\begin{array}{l}\text { Yes } \\
\text { FDA }\end{array}$ & $95 \%$ \\
\hline (24)Walsh & 195 & $\begin{array}{l}\text { I (RCT dose } \\
\text { escalation) }\end{array}$ & $\begin{array}{c}\text { Both } \\
\text { BNT162b1 and } \\
\text { BNT162b2 }\end{array}$ & & & \\
\hline $\begin{array}{c}\text { (21)Xia } \\
\text { (25)Xia-2 } \\
\text { ChiCTR2000031809 }\end{array}$ & $\begin{array}{c}1^{\text {st }} \text { RCT } 96 \\
2^{\text {nd }} \text { RCT } 224\end{array}$ & I-II (RCT) & $\begin{array}{c}\text { Whole } \\
\text { inactivated }\end{array}$ & $\begin{array}{l}\text { China } \\
\text { by Sinopharm } \\
\text { (Beijing } \\
\text { Institute of } \\
\text { Biological } \\
\text { Products) }\end{array}$ & No & $\begin{array}{c}\text { Increased } \\
\text { antibody } \\
\text { response after } 14 \\
\text { days }\end{array}$ \\
\hline $\begin{array}{c}\text { (10)Sadoff } \\
\text { NCT04436276 }\end{array}$ & $\begin{array}{l}805 \text { patients in } \\
\text { cohort } 1 \text { and } 3 \\
\\
\text { Cohort 1: } 18 \text { and } \\
55 \text { years ( } 402 \\
\text { participants divided } \\
\text { into 1a and 1b) } \\
\text { Cohort 3: } \geq 65 \text { years } \\
\text { (403 participants) } \\
\text { Cohort 2: long term } \\
\text { effects of single dose } \\
\text { versus two doses }\end{array}$ & I-IIa RCT & $\begin{array}{l}\text { Vector carrier } \\
\text { Ad26 of the } \\
\text { whole spike } \\
\text { protein } \\
\text { sequence }\end{array}$ & $\begin{array}{c}\text { Belgium } \\
\text { and USA by } \\
\text { Johnson and } \\
\text { Johnson }\end{array}$ & No & $\begin{array}{l}\text { Neutralizing } \\
\text { antibodies in } \\
90 \% \text { or more of } \\
\text { all participants } \\
\text { on day } 29 \text { after } \\
\text { the first vaccine } \\
\text { dose } \\
\text { Cellular response } \\
\text { in } 60-80 \% \text { of } \\
\text { participants }\end{array}$ \\
\hline
\end{tabular}




\begin{tabular}{|c|c|c|c|c|c|c|}
\hline $\begin{array}{c}\text { (4)Zhu } \\
\text { NCT04341389 }\end{array}$ & $\begin{array}{c}603 \\
\text { Vaccine: } 253 \text { to } 1 . \\
10^{11} \\
\text { Vaccine: } 129 \text { to } 5 \\
10^{10} \\
\text { plcebo: } 126\end{array}$ & $\begin{array}{c}\text { II (RCT- } \\
\text { double blind) }\end{array}$ & \multirow[t]{2}{*}{$\begin{array}{l}\text { Recombinant } \\
\text { adenovirus } \\
\text { type-5 } \\
\text { vectored }\end{array}$} & \multirow{2}{*}{$\begin{array}{c}\text { China by } \\
\text { CanSino } \\
\text { Biologics', } \\
\text { Tianjin }\end{array}$} & \multirow[t]{2}{*}{ No } & \multirow{2}{*}{$\begin{array}{c}\text { Increased } \\
\text { antibody and } \\
\text { T-Cell response } \\
\text { post vaccination }\end{array}$} \\
\hline $\begin{array}{c}\text { (5)Zhu-2 } \\
\text { NCT04313127 }\end{array}$ & $\begin{array}{l}108(18-60 y) \\
36 \text { each in (low, } \\
\text { middle and high } \\
\text { dose) groups }\end{array}$ & $\begin{array}{l}\text { Phase I (non } \\
\text { RCT-open } \\
\text { label dose } \\
\text { escalation) }\end{array}$ & & & & \\
\hline
\end{tabular}

Table 1: Table showing; trial registry numbers, phase of the trial and number of participants, country, vaccine names and company producing the vaccines, approval by FDA and protection rate/outcome effect.

Mass-vaccination already started in "priority tiers"; where healthcare workers, and patients most susceptible as; the elderly and the immune-compromised with high risk for acquiring severe COVID-19 form the first tier [12].

On the other hand; there are some reports of vaccination refusal in the first wave of the priority tier reaching up to $50 \%$ in healthcare and public workers [13]. However; there is no legalization till the time-being on how to move to the next tier in the US, so the excess doses are mostly given to any worker who is willing to be vaccinated in the vicinity of the healthcare facility till now, this decision is taken mainly to avoid the expiration of the vaccine doses once they are thawed. Some studies warned of this effect as a result of individuals' hesitancy to vaccination that has risen in the last decade and the global distrust of the health authorities due to inefficient handling of the pandemic in its initial phase [14].

2. Efficacy And Effectiveness of The Vaccine In Prevention Of Infection shown in table 1:

The main problem with the primary outcome is; the short duration of follow-up to the outcome for example 14 days after the first dose [7] or two weeks after the second [15]. This is acceptable in determining short-time adverse effects, but lacking in case of long-term adverse effects and determining the long-term protective efficacy from infection. We anticipate that further data will be published timely, but we hope that they are presented once they are available and not delayed in their public presentation.

Another problem is the high dropping rate that is noticed in some studies especially as high as $>20 \%$ missing data in BNT162b2 vaccine (Pfizer) [16], those patients either didn't receive the second dose or failed to report their outcome which might weaken the results of the study.

3. Side Effects (Systemic And Local); from CDC And WHO Sites

Higher doses of the vaccines are mostly associated with either incompliance of the patients; where patients refuse to receive the second dose or suffer more complications [8].

The most common complications included; local injection site reactions (pain, swelling, redness) or systemic constitutional symptoms as headache, rashes, fever, myalgia and fatigue.

All of the studies didn't report serious adverse effects but Cansino study reported severe adverse effects in $>70 \%$ of the vaccine groups. The events ranged from [4] fatigue, fever, headache, pain and swelling at the injection site, vomiting, diarrhea, muscle and joint pain.

\section{Notes On Mortality}

Reports on mortality started to appear post-mass release of the vaccine; where in Norway 23 elderly participants died post vaccination [2]. Some clinicians attributed this to; the prioritization in Norway and the reporting system of the patients' mortality. Prioritization is different from the US and England; where healthcare workers are first tier, while in Norway the first tier is the elderly at risk, but it seems that the healthcare authorities didn't find a link between the mortality and the side effects of the vaccine and will continue without any modification of their vaccination system.

In US and England there are some individual cases of mortality among health care workers as reported in the news but no published scientific data are available while 
it is reported from Pfizer that there is no link between the deaths and the vaccination [17].

Four participants died during phase III of the Russian vaccine; one in the placebo group and three in the vaccine group, but the authors denied that their death had any relation to the vaccine [11].

\section{Notes On Troubles With Clinical Trials Outcomes}

A Brazilian study showed that the efficacy of the Sinovac vaccine slightly exceeding $50 \%$ [15], no publication is found till the time being, but this efficacy is very low to guarantee effectiveness on mass vaccination.

Despite the promising results of the Russian vaccine in phase I-II trials with $100 \%$ Seroconversion [3], the number of patients is very low as this is mainly to determine safety, also the preventive effect of this Seroconversion from infection is still unknown (we note that Seroconversion is a "surrogate marker" for protection from infection). The same occurred in phase I-II trials in Pfizer [18] by using the antibody titer response post-vaccination, but phase III they used the clinical outcome of infection rate [7].

On the other hand; we noticed that phase III trials included an adequate number of participants with more than 20,000 in each study. The efficacy of prevention of infection ranged from $50-95 \%$ as shown in table 1.

\section{Dosing differences across trials: table 2}

Most of the control groups received the placebo in the form of saline injection; and while the patients were at first blinded, later when there was no adverse events either local or general the patient may suspect that he or she are actually in the control group thus may stop the participation in the study. This may account for the high rate of drop out noticed in most of the control groups. Which explains why the Australian study used a control vaccine in the form of MenACWY vaccine to avoid the "unblinding" and this indeed decreased the drop out in the control group [19].
Some trials assigned all groups to two vaccine doses as Pfizer, while others designed some arms of the trial that received only one dose or two doses as the AstraOxford vaccine $[19,20]$. This different design depended on published or unpublished preliminary trials. Cansino vaccine trial didn't determine the time suitable for the booster dose yet $[4,5]$. While the Sinopharm vaccine was in three intramuscular doses [21].

In addition; Johnson and Johnson vaccine showed lower side effects with the lower dose groups. Interestingly; it also showed high immunogenicity after a single dose [10].

7. The Fact That This Pandemic Is Taking Long Time And Affecting Children

One of the most vulnerable groups that may wait for a long time before being considered in the vaccination program is the pediatric group. Issues of safety and strict measures for protection are the main concern. On the other hand; while the toll of COVID-19 infection on children is different in symptomatology, presentation and mortality. In addition; it plays an important role in viral spreading and morbidity among pediatric population [26].

\section{Effect of the vaccine in old age}

Added to the mortality issue mentioned earlier; there was a subgroup of Moderna study phase I which included 40 elderly patients and showed that the adverse events were mild to moderate. The adverse events were noted directly related to increasing the dose of the vaccine and particularly on the second vaccination dose (boost dose) [18]. This may signify the importance of decreasing the vaccine doses or widening the duration between the first and second doses in the elderly.

On the other hand; it was noticed that Johnson and Johnson vaccine showed surprisingly lower side effects in the elderly participants than with the young [10].

An interesting study showed that; BCG vaccination could cause protection of respiratory tract infection in the elderly with good safety profile [27]. 


\begin{tabular}{|c|c|c|c|}
\hline Vaccine company & Dose & Duration & Primary endpoint \\
\hline Moderna & $\begin{array}{l}\text { Phase I: } 25 \mu \mathrm{g} \text { or } 100 \mu \mathrm{g} \text { [22] } \\
\text { Phase III } 100 \mu \mathrm{g}[7]\end{array}$ & 28 days apart & 14 days after $1^{\text {st }}$ dose \\
\hline Pfizer-BioNTech & $\begin{array}{l}\text { Phase III: } 30-\mu \mathrm{g} \text { doses [16] } \\
\text { Elderly: [18] } 25 \mu \mathrm{g} \text { or } 100 \mu \mathrm{g}\end{array}$ & $\begin{array}{l}21 \text { days apart } \\
28 \text { apart }\end{array}$ & 7 days after the second dose \\
\hline BNT162b1 (Pfizer) & $\begin{array}{c}\text { [1] } 1 \mu \mathrm{g}, 10 \mu \mathrm{g}, 30 \mu \mathrm{g} \text {, and } 50 \mu \mathrm{g}) \\
\text { [8] } 10 \mu \mathrm{g}, 30 \mu \mathrm{g} \text { or } 100 \mu \mathrm{g}\end{array}$ & $\begin{array}{l}22 \text { days apart } \\
21 \text { days apart }\end{array}$ & T-cell and antibody response \\
\hline Astra-Oxford & $\begin{array}{c}{[19] 5 \times 10^{10} \text { viral particles }} \\
{[20]} \\
{[9]}\end{array}$ & 28 days apart & Spike protein antibody response \\
\hline Novavax & [6] 5- $\mu$ g and $25-\mu \mathrm{g}$ doses & 21 days apart & T-cell and antibody response \\
\hline Sinopharm & $\begin{array}{c}{[21]} \\
(2.5,5 \text {, and } 10 \mu \mathrm{g} / \mathrm{dose}) \text { and an } \\
\text { aluminum hydroxide (alum) adjuvant- } \\
\text { only group }\end{array}$ & $\begin{array}{c}3 \text { intramuscular } \\
\text { injections at days } 0 \text {, } \\
28 \text {, and } 56 \text {. }\end{array}$ & $\begin{array}{l}\text { Adverse reactions after } 7 \text { days and } \\
\text { antibody response after } 14 \text { days }\end{array}$ \\
\hline Cansino & $\begin{array}{c}{[4,5]} \\
\left(5 \times 10^{10}, 1 \times 10^{11} \text {, and } 1.5 \times 10^{11} \text { viral }\right. \\
\text { particles })\end{array}$ & $\begin{array}{l}\text { No booster dose } \\
\text { determined yet }\end{array}$ & $\begin{array}{l}\text { Adverse reactions after } 14 \text { days } \\
\text { Antibody and T-cell response after } \\
28 \text { days }\end{array}$ \\
\hline Sinovac & [15] $3 \mu \mathrm{g} / 0.5 \mathrm{~mL}$ & $\begin{array}{l}2 \text { weeks between the } \\
\text { two doses }\end{array}$ & $\begin{array}{l}\text { Symptomatic cases } 2 \text { weeks after } \\
\text { the second vaccination }\end{array}$ \\
\hline \multirow[t]{2}{*}{ Russian vaccine } & [3] $10^{11}$ viral particles & $\begin{array}{c}28 \text { days post- } \\
\text { vaccination in phase I } \\
42 \text { days } \\
\text { postvaccination in } \\
\text { phase II }\end{array}$ & Safety and immunogenicity \\
\hline & $\begin{array}{c}\text { [11] Phase III: } \\
0 \cdot 5 \mathrm{~mL} / \text { dose intramuscularly }\end{array}$ & 2 doses 21 days apart & Efficacy \\
\hline Johnson and Johnson & $\begin{array}{l}{[10] \text { low dose : } 5 \times 10^{10}} \\
\text { viral particles or high dose } 1 \times 10^{10} \text { viral } \\
\text { particles per milliliter }\end{array}$ & $\begin{array}{l}\text { Single dose or two } \\
\text { doses } 56 \text { days apart }\end{array}$ & $\begin{array}{l}\text { 1ry endpoint: The safety and } \\
\text { reactogenicity } \\
\text { 2ry endpoint: humoral and cellular } \\
\text { immunity }\end{array}$ \\
\hline
\end{tabular}

Table 2: Table showing; vaccination doses, duration between the first and boost vaccines and the primary outcomes of the study. 


\section{REFERENCES}

9. Sahin U, Muik A, Derhovanessian E, Vogler I, Kranz LM, et al. (2020). COVID-19 vaccine BNT162b1 elicits human antibody and $\mathrm{T}(\mathrm{H}) 1 \mathrm{~T}$ cell responses. Nature. 586(7830):594-9.

10. Torjesen I. (2021). Covid-19: Norway investigates 23 deaths in frail elderly patients after vaccination. BMJ. 372:n149.

11. Logunov DY, Dolzhikova IV, Zubkova OV, Tukhvatulin AI, Shcheblyakov DV, et al. (2020). Safety and immunogenicity of an rAd26 and rAd5 vector-based heterologous prime-boost COVID-19 vaccine in two formulations: two open, non-randomised phase $1 / 2$ studies from Russia. Lancet. 396(10255):887-97.

12. Zhu FC, Guan XH, Li YH, Huang JY, Jiang T, et al. (2020). Immunogenicity and safety of a recombinant adenovirus type-5-vectored COVID-19 vaccine in healthy adults aged 18 years or older: a randomised, double-blind, placebocontrolled, phase 2 trial. Lancet. 396(10249):479-88.

13. Zhu FC, Li YH, Guan XH, Hou LH, Wang WJ, et al. (2020). Safety, tolerability, and immunogenicity of a recombinant adenovirus type-5 vectored COVID-19 vaccine: a doseescalation, open-label, non-randomised, first-in-human trial. Lancet. 395(10240):1845-54.

14. Keech C, Albert G, Cho I, Robertson A, Reed P, et al (2020). Phase 1-2 Trial of a SARS-CoV-2 Recombinant Spike Protein Nanoparticle Vaccine. N Engl J Med. 383(24):2320-32.

15. Baden LR, El Sahly HM, Essink B, Kotloff K, Frey S, et al. (2020). Efficacy and Safety of the mRNA-1273 SARSCoV-2 Vaccine. New England Journal of Medicine.

16. Mulligan MJ, Lyke KE, Kitchin N, Absalon J, Gurtman A, et al. (2020). Phase I/II study of COVID-19 RNA vaccine BNT162b1 in adults. Nature. 586(7830):589-93.

17. Voysey M, Clemens SAC, Madhi SA, Weckx LY, Folegatti PM, et al. (2021). Safety and efficacy of the ChAdOx1 nCoV-19 vaccine (AZD1222) against SARS-CoV-2: an interim analysis of four randomised controlled trials in Brazil, South Africa, and the UK. The Lancet. 397(10269):99-111.

18. Sadoff J, Le Gars M, Shukarev G, Heerwegh D, Truyers C, et al. (2021). Interim Results of a Phase 1-2a Trial of Ad26.COV2.S Covid-19 Vaccine. New England Journal of Medicine.
19. Logunov DY, Dolzhikova IV, Shcheblyakov DV, Tukhvatulin AI, Zubkova OV, et al. (2021). Safety and efficacy of an rAd 26 and rAd5 vector-based heterologous prime-boost COVID-19 vaccine: an interim analysis of a randomised controlled phase 3 trial in Russia. The Lancet.

20. ECDC. COVID-19 vaccination and prioritisation strategies in the EU/EEA. European Centre for Disease Prevention and Control 22 December 2020.

21. Shalby C. Baumgaertner E, Branson-Potts H, ReyesVelarde A, Dolan J. Some healthcare workers refuse to take COVID-19 vaccine, even with priority access Los Angeles Times. 31 Dec 2020.

22. Group C. (2020). A future vaccination campaign against COVID-19 at risk of vaccine hesitancy and politicisation. Lancet Infect Dis. 20(7):769-70.

23. Palacios R, Patiño EG, de Oliveira Piorelli R, Conde $M$, Batista AP, et al. (2020). Double-Blind, Randomized, Placebo-Controlled Phase III Clinical Trial to Evaluate the Efficacy and Safety of treating Healthcare Professionals with the Adsorbed COVID-19 (Inactivated) Vaccine Manufactured by Sinovac - PROFISCOV: A structured summary of a study protocol for a randomised controlled trial. Trials. 21(1):853.

24. Polack FP, Thomas SJ, Kitchin N, Absalon J, Gurtman A, et al. (2020). Safety and Efficacy of the BNT162b2 mRNA Covid-19 Vaccine. N Engl J Med. 383(27):2603-15.

25. Griffin R. Pfizer investigates death of healthcare worker who received first dose of Covid vaccine. The Print. 2021.

26. Anderson EJ, Rouphael NG, Widge AT, Jackson LA, Roberts PC, et al. (2020). Safety and Immunogenicity of SARS-CoV-2 mRNA-1273 Vaccine in Older Adults. N Engl J Med. 383(25):2427-38.

27. Folegatti PM, Ewer KJ, Aley PK, Angus B, Becker S, et al. (2020). Safety and immunogenicity of the ChAdOx1 nCoV-19 vaccine against SARS-CoV-2: a preliminary report of a phase 1/2, single-blind, randomised controlled trial. Lancet. 396(10249):467-78.

28. Ramasamy MN, Minassian AM, Ewer KJ, Flaxman AL, Folegatti PM, et al. (2021). Safety and immunogenicity of ChAdOx1 nCoV-19 vaccine administered in a primeboost regimen in young and old adults (COV002): a single-blind, randomised, controlled, phase $2 / 3$ trial. Lancet. 396(10267):1979-93. 
29. Xia S, Duan K, Zhang Y, Zhao D, Zhang H, et al. (2020). Effect of an Inactivated Vaccine Against SARS-CoV-2 on Safety and Immunogenicity Outcomes: Interim Analysis of 2 Randomized Clinical Trials. Jama. 324(10):951-60.

30. Jackson LA, Anderson EJ, Rouphael NG, Roberts PC, Makhene M, et al. (2020). An mRNA Vaccine against SARS-CoV-2 - Preliminary Report. N Engl J Med. 383(20):1920-31.

31. P. R. Sinovac: Brazil results show Chinese vaccine $50.4 \%$ effective. BBCnews. Jan 2021.

32. Walsh EE, Frenck RW, Jr., Falsey AR, Kitchin N, Absalon J, et al. (2020). Safety and Immunogenicity of Two RNA-Based Covid-19 Vaccine Candidates. N Engl J Med. 383(25):2439-50.
33. Xia S, Zhang Y, Wang Y, Wang H, Yang Y, et al. (2021). Safety and immunogenicity of an inactivated SARSCoV-2 vaccine, BBIBP-CorV: a randomised, double-blind, placebo-controlled, phase $1 / 2$ trial. Lancet Infect Dis. 21(1):39-51.

34. Patel NA. (2020). Pediatric COVID-19: Systematic review of the literature. American Journal of Otolaryngology. 41(5):102573.

35. Giamarellos-Bourboulis EJ, Tsilika M, Moorlag S, Antonakos N, Kotsaki A, et al. (2020). Activate: Randomized Clinical Trial of BCG Vaccination against Infection in the Elderly. Cell. 183(2):315-23.e9. 